\title{
Is Buying and Drinking Zero and Low Alcohol Beer a Higher Socio-Economic Phenomenon? Analysis of British Survey Data, 2015-2018 and Household Purchase Data 2015-2020
}

\author{
Peter Anderson ${ }^{1,2, *}$, Amy $\mathrm{O}^{\prime}$ Donnell $^{1}{ }^{(\mathbb{D}}$, Daša Kokole ${ }^{2}\left(\mathbb{D}\right.$, Eva Jané Llopis ${ }^{2,3,4}$ and Eileen Kaner $^{1}(\mathbb{D}$ \\ 1 Population Health Sciences Institute, Newcastle University, Baddiley-Clark Building, \\ Newcastle NE2 4AX, UK; amy.odonnell@newcastle.ac.uk (A.O.); Eileen.kaner@newcastle.ac.uk (E.K.) \\ 2 Department of Health Promotion, CAPHRI Care and Public Health Research Institute, Maastricht University, \\ 6211 LK Maastricht, The Netherlands; d.kokole@maastrichtuniversity.nl (D.K.); eva.jane@esade.edu (E.J.L.) \\ 3 Institute for Mental Health Policy Research, Centre for Addiction and Mental Health, \\ Toronto, ON M5T 1R8, Canada \\ 4 ESADE Business School, Ramon Llull University, 08034 Barcelona, Spain \\ * Correspondence: peteranderson.mail@gmail.com
}

Citation: Anderson, P.; O'Donnell, A.; Kokole, D.; Jané Llopis, E.; Kaner, E. Is Buying and Drinking Zero and Low Alcohol Beer a Higher Socio-Economic Phenomenon? Analysis of British Survey Data, 2015-2018 and Household Purchase Data 2015-2020. Int. J. Environ. Res. Public Health 2021, 18, 10347. https:// doi.org/10.3390/ijerph181910347

Academic Editors: Charlotte Probst and Shannon Lange

Received: 30 August 2021

Accepted: 29 September 2021

Published: 30 September 2021

Publisher's Note: MDPI stays neutral with regard to jurisdictional claims in published maps and institutional affiliations.

Copyright: (c) 2021 by the authors. Licensee MDPI, Basel, Switzerland. This article is an open access article distributed under the terms and conditions of the Creative Commons Attribution (CC BY) license (https:/ / creativecommons.org/licenses/by/ $4.0 /)$.

\begin{abstract}
Zero and low alcohol products, particularly beer, are gaining consideration as a method to reduce consumption of ethanol. We do not know if this approach is likely to increase or decrease health inequalities. The aim of the study was to determine if the purchase and consumption of zero and low alcohol beers differs by demographic and socio-economic characteristics of consumers. Based on British household purchase data from 79,411 households and on British survey data of more than 104,635 adult (18+) respondents, we estimated the likelihood of buying and drinking zero $(\mathrm{ABV}=0.0 \%)$ and low alcohol $(\mathrm{ABV}>0.0 \%$ and $\leq 3.5 \%$ ) beer by a range of socio-demographic characteristics. We found that buying and consuming zero alcohol beer is much more likely to occur in younger age groups, in more affluent households, and in those with higher social grades, with gaps in buying zero alcohol beer between households in higher and lower social grades widening between 2015 and 2020. Buying and drinking low alcohol beer had less consistent relationships with sociodemographic characteristics, but was strongly driven by households that normally buy and drink the most alcohol. Common to many health-related behaviours, it seems that it is the more affluent that lead the way in choosing zero or low alcohol products. Whilst the increased availability of zero and low alcohol products might be a useful tool to reduce overall ethanol consumption in the more socially advantageous part of society, it may be less beneficial for the rest of the population. Other evidence-based alcohol policy measures that lessen health inequalities, need to go hand-in-hand with those promoting the uptake of zero and low alcohol beer.
\end{abstract}

Keywords: no and low alcohol beer; social determinants; household purchases

\section{Introduction}

Alcohol use is a leading risk factor for ill-health and premature death [1,2]. The World Health Organization (WHO) has set a global target to reduce the harmful use of alcohol by $10 \%$ between 2010 and 2025 [3]. The WHO SAFER initiative calls on governments at all levels to: (I) Strengthen restrictions on alcohol availability; (II) Advance and enforce drink driving counter measures; (III) Facilitate access to screening, brief interventions and treatment; (IV) Enforce bans or comprehensive restrictions on alcohol advertising, sponsorship, and promotion; and (V) Raise prices on alcohol through excise taxes and pricing policies [4]. However, as stressed in WHO's global alcohol strategy, there is also potential for the alcohol industry to contribute to these efforts by addressing the composition of its products [5], by, for example, reducing the amount of ethanol they contain [6]. In recent years, this appears to be gaining consideration amongst policy makers as well as in global alcohol markets [7,8]. Although not without public health advocates' 
concern related to product descriptors and marketing [9], in its consultation document, 'Advancing our health: prevention in the 2020s' the UK Government made a commitment to work with the drinks industry to "deliver a significant increase in the availability of alcohol-free and low-alcohol products by 2025" [10].

Previously, we have shown that the introduction of new lower strength beers resulted in British households purchasing fewer grams of ethanol overall [11]. From 2015 to 2018, the introduction of 46 new zero or low alcohol (defined as 3.5\% Alcohol by Volume (ABV) or less) beers was associated with reductions in purchases of grams of ethanol across all beer products and across all alcohol products [11]. Despite several evidence reviews concerning zero and low alcohol beer specifically $[12,13]$, there remains a dearth of studies investigating which factors influence the actual purchasing and consumption of these products. Qualitative evidence suggests that choosing specific lower strength products tends to be driven by previous consumption of higher strength products from the same brand [14]. Other studies indicate that health and wellbeing issues, price differentials, and overall decreases in the social stigma associated with drinking alcohol-free beverages may also drive decisions to buy and consume zero and low alcohol beers [15].

Although there is some limited grey literature on the topic [16], we do not know if the purchase and consumption of zero and low alcohol beers is influenced by demographic and socio-economic characteristics of consumers, and whether it occurs across all socio-economic groups, or it is restricted to more advantaged socio-economic groups. Using British survey data and British household purchase data, the aim of the study is to determine if the likelihood of buying and drinking zero alcohol beer and low alcohol beer differs by gender, age, social grade group, income, level of area-based residential deprivation, and region of Great Britain.

\section{Methods}

\subsection{Study Design}

We undertook binary logistic cross-sectional regression analyses to estimate the likelihood of drinking or buying zero alcohol beer or low alcohol beer by socio-demographic characteristics of respondents using online survey data and household purchase data.

\subsection{Data Sources}

We used two data sources: (1) household purchase data that capture numbers of adults in the household, age of the main shopper, social grade group of the household, household income, level of area-based residential deprivation, and region of Great Britain (as household purchase data captures data for the whole household, there is no specific data by gender); and (2) survey data that captures for each respondent, sex, age, social grade, level of area-based residential deprivation, and region of Great Britain. These are described in detail below.

\subsection{Household Purchase Data}

We used data from Kantar Worldpanel's (KWP) household shopping panel for the years 2015 to 2020, the years for which we had data. The shopping panel comprises approximately 30,000 British households at any one time, recruited via stratified sampling, with targets set for region, household size, age of main shopper, and occupational group. Households record all off-trade purchases from all store types, including Internet shopping, brought back into the home using barcode scanners. To be included in KWP's final datasets, households must meet quality control criteria (meeting thresholds for data recording and purchasing volume or spend (based on household size) every four weeks), with some 90-95\% of households included [17]. In our sample, out of 79,411 households providing purchase data on 5.02 million separate alcohol purchases, 11,598 households (14.6\%) did not provide household income data. Missing income data were imputed using monotonic multiple imputation [18]. There was no other missing data. 
The data included the truncated postcode of each household (up to first four characters, two letters and two numbers). Alcohol purchases are recorded daily. For each individual purchase, the data includes the type and volume of the purchase using 19 drink categories, the brand, and the alcohol by volume (ABV). The volume purchased was combined with $\mathrm{ABV}$ to calculate grams of alcohol purchased.

We grouped households into: (I) four groups of the age of the main shopper (18-34; 35-44; 45-64; and 65+ years); (II) four occupation-based social grade groups (AB ('highest'), $\mathrm{C} 1, \mathrm{C} 2, \mathrm{DE}$ ('lowest'))with $\mathrm{AB}$ including higher and intermediate managerial, administrative or professional workers, $\mathrm{C} 1$ supervisory or clerical and junior managerial, administrative or professional workers, C2 skilled manual workers, and DE semiskilled and unskilled manual workers, state pensioners, casual and lowest grade workers, and unemployed with state benefits only based on the National Readership Survey [19]; (III) four similar sized household income groups $(£ 0-8.75 \mathrm{k} ;>£ 8.75-15 \mathrm{k} ;>£ 15-22.5 \mathrm{k}$; and $>£ 22.5 \mathrm{k}$ per adult per household per year); (IV) four similar sized groups of the number of grams of all alcohol regularly purchased $(>0-7 ;>7-21 ;>21-70$; and $>70 \mathrm{~g}$ of alcohol purchased per adult per household per week, averaged over the total number of days between first and last recorded day of an alcohol purchase); and, (V) four similar sized groups of area-based residential deprivation ranging from 1 (most deprived) to 4 (least deprived) based on multiple indices of ranking of residential deprivation aggregated at truncated postcode level with the lowest number of ranking the most deprived, and the highest number of ranking the least deprived for each of England [20], Scotland [21], and Wales [22]. The multiple indices include measures of income, employment, education, health, crime, access to housing, and environmental quality.

We classified three beer groups: zero-alcohol beer with an $\mathrm{ABV}=0.0 \%$; low-alcohol beer with an $\mathrm{ABV}>0.0 \%$ and $\leq 3.5 \%$; and all other beer with an $\mathrm{ABV}>3.5 \%$.

\subsection{Alcovision Survey Data}

We used data from Kantar WorldPanel (KWP) Alcovision survey for the years 2015-2018, the years for which we had data. Alcovision is an ongoing cross-sectional online timeline follow-back (TLFB) diary survey of the previous week's alcohol consumption, with an annual sample of approximately 30,000 individuals aged 18+ years in Great Britain. In the diary-based approach, participants provide detailed data on the consumption of alcohol during the previous seven days for each day. Each drink by named brand is recorded, with the volume consumed and whether the consumed drink was purchased on-trade (pubs, bars, restaurants, etc.) or off-trade (supermarkets, shops, etc.). Participants complete the survey only once, without repeated surveys. Quota samples based on age, sex, social grade group based on occupation, and geographic region are drawn from Kantar's managed access panel. Invitations to participate are sent out on set dates and timed such that completion dates of the survey occurs every month, and each day of the year is represented in the data. Weights based on age-sex groups, social class, and geographical region are constructed using UK census data to ensure representativeness of British adults, with 18-34-year-olds oversampled.

Drink diaries were completed by 104,635 respondents (53,409 men and 51,226 women) during the four years from 2015 to 2018, with an average of 512 diaries per week, (SD = 173), a rate which remained stable over the four-year period $(\mathrm{F}=0.544, p=0.462)$.

The data includes the truncated postcode of each respondent (up to first four characters, two letters and two numbers). The number of drinks consumed by brand is recorded separately for on-and off-trade, with information given on serving sizes in millilitres $(\mathrm{mL})$. Drinks are categorized into 19 categories. For beer products, the brand-specific ABVs from household purchase data were used [11]. There was no missing data.

We grouped respondents into (I) male or female; (II) four age groups (18-34; 35-44; 45-64; and 65+ years); (III) the same four occupation-based social grade groups as for the household purchase data (AB ('highest'), C1, C2, DE ('lowest')), based on the National Readership Survey [18]; (IV) four similar sized groups of the number of grams of all 
alcohol consumed during the previous week $(\leq 100 ;>100$ to $\leq 200 ;>200$ to $\leq 350$; and, $>350$ ); and, (V) four similar sized groups of area-based residential deprivation ranging from 1 (most deprived) to 4 (least deprived) based on multiple indices of residential deprivation aggregated at truncated postcode level for each of England [20], Scotland [21], and Wales [22].

We classified three beer groups: zero-alcohol beer with an $\mathrm{ABV}=0.0 \%$; low-alcohol beer with an $\mathrm{ABV}>0.0 \%$ and $\leq 3.5 \%$; and all other beer with an $\mathrm{ABV}>3.5 \%$.

\subsection{Statistical Analyses}

We undertook separate binary logistic regression analyses for the purchase data and the survey data, using both univariate (individual models for each independent variable) and multivariate (with all independent variables in the model) analyses. For the purchase data, the dependent variables were binary variables at the level of the household, had or had not ever purchased any of zero or low alcohol beer on any day of purchase of any alcohol product. For the survey data, the dependent variables were binary variables at the level of the respondent, had or had not consumed any of zero or low alcohol beer during the previous week. For the purchase data, we added date of first alcohol purchase and number of days between first and last purchase of any alcohol as covariates. For the survey data, we added date of completing the survey as a covariate.

For all analyses, we report odds ratios with $95 \%$ confidence intervals. All analyses were performed with SPSSv26 (IBM, Armonk, NY, USA) [23].

\section{Results}

\subsection{Household Purchase Data}

Based on the household purchase data, for any day that a household made an alcohol purchase, $0.92 \%(95 \% \mathrm{CI}=0.91$ to 0.94$)$ of households reported at least one purchase of zero alcohol beer, $2.17 \%$ (95\% CI $=2.16$ to 2.18$)$ of low alcohol beer and $29.32 \%(95 \% \mathrm{CI}=29.26$ to 29.38) of all other beer, Figure 1 (please note that the left vertical axis is for low and zero alcohol beer; and, the right vertical axis is for all other beer). The proportions of purchase of zero alcohol beer increased over time, whilst the proportions of low alcohol beer decreased over time. The proportion of all other beer showed a gradual increase over time, with an upwards blip during 2020 that coincided with the COVID-19 lockdown [24].

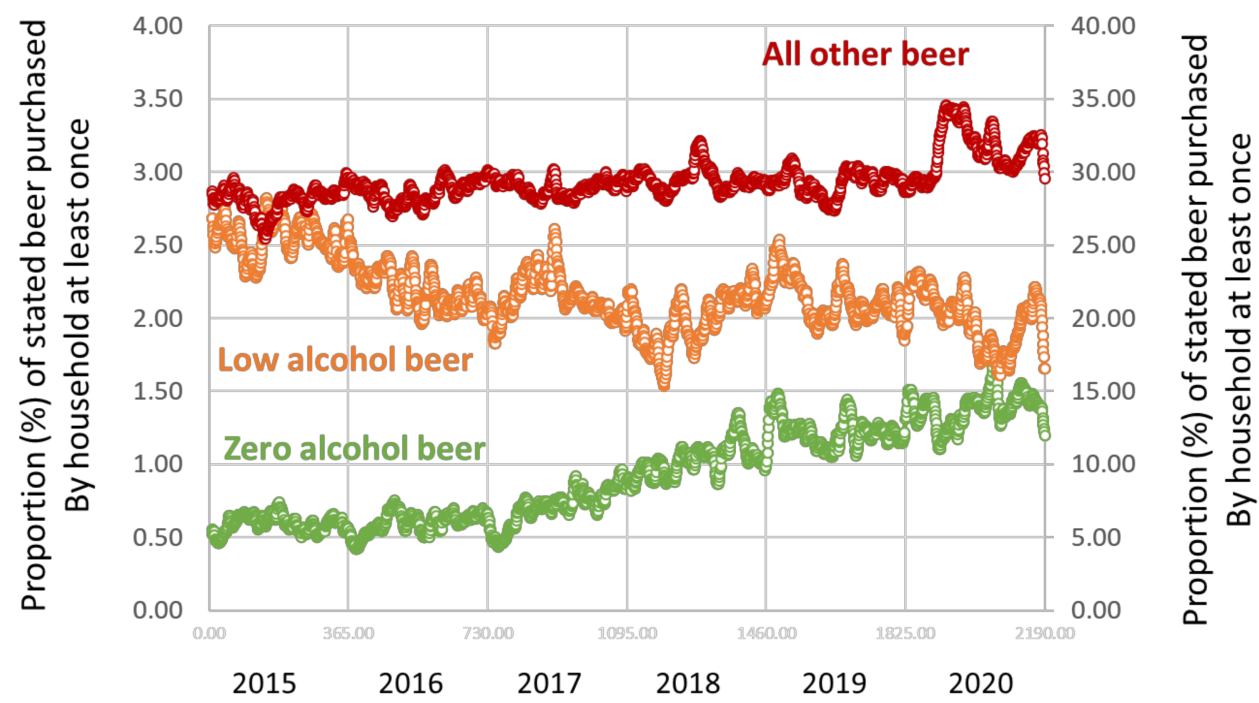

Figure 1. Proportion (\%) of households that reported at least one purchase of zero alcohol beer (green, left vertical axis), low alcohol beer (orange, left vertical axis) and all other beer (red, right vertical axis) for any day that a household made an alcohol purchase by study day, 2015 to 2020. Data points: daily. 
Table 1 gives the odds ratios (95\% confidence intervals) for a household purchasing at least one zero alcohol beer and at least one low alcohol beer by household characteristics.

Table 1. Analysis at level of each household; odds ratios (OR) (95\% confidence intervals) for any purchase of zero alcohol beer $(\mathrm{ABV}=0.0 \%)$ or low alcohol beer $(\mathrm{ABV}>0.0 \%$ and $\leq 3.5 \%)$ by household socio-demographic characteristics. In bold: $95 \%$ confidence interval does not cross 1.0 .

\begin{tabular}{|c|c|c|c|c|c|c|}
\hline & & & \multicolumn{2}{|c|}{ Zero Alcohol Beer } & \multicolumn{2}{|c|}{ Low Alcohol Beer } \\
\hline & $\begin{array}{l}\text { Characteristics of } \\
\text { Consumers (Please } \\
\text { See Methods Section } \\
\text { for More Detail) }\end{array}$ & $n$ & $\begin{array}{l}\text { Univariate } \\
\text { Analysis }\end{array}$ & $\begin{array}{l}\text { Multivariate } \\
\text { Analysis }\end{array}$ & $\begin{array}{l}\text { Univariate } \\
\text { Analysis }\end{array}$ & $\begin{array}{c}\text { Multivariate } \\
\text { Analysis }\end{array}$ \\
\hline \multirow{4}{*}{$\begin{array}{l}\text { Total grams of } \\
\quad \text { alcohol } \\
\text { purchased per } \\
\text { week per adult }\end{array}$} & $>70$ & 18,192 & $\begin{array}{c}1.147(1.053 \text { to } \\
1.250)\end{array}$ & $\begin{array}{c}1.132 \text { (1.038 to } \\
1.236)\end{array}$ & $\begin{array}{c}1.636(1.538 \text { to } \\
1.741)\end{array}$ & $\begin{array}{c}1.587(1.488 \text { to } \\
1.692)\end{array}$ \\
\hline & $>21$ to $\leq 70$ & 22,882 & $\begin{array}{c}1.363(1.264 \text { to } \\
1.470)\end{array}$ & $\begin{array}{c}1.217(1.126 \text { to } \\
1.315)\end{array}$ & $\begin{array}{c}2.071 \text { (1.960 to } \\
2.189)\end{array}$ & $\begin{array}{c}1.768(1.670 \text { to } \\
1.871)\end{array}$ \\
\hline & $>7$ to $\leq 21$ & 21,269 & $\begin{array}{c}0.999(0.922 \text { to } \\
1.082)\end{array}$ & $\begin{array}{c}0.908 \text { ( } 0.837 \text { to } \\
0.985)\end{array}$ & $\begin{array}{c}1.582(1.495 \text { to } \\
1.675)\end{array}$ & $\begin{array}{c}1.399(1.320 \text { to } \\
1.483)\end{array}$ \\
\hline & $\leq 7$ (reference category) & 17,068 & 1.000 & 1.000 & 1.000 & 1.000 \\
\hline \multirow{2}{*}{$\begin{array}{l}\text { Purchased any } \\
\text { other beer with } \\
\text { ABV }>3.5 \%\end{array}$} & Yes & 56,503 & $\begin{array}{l}2.273(2.090 \text { to } \\
2.472)\end{array}$ & $\begin{array}{c}2.180(2.002 \text { to } \\
2.375)\end{array}$ & $\begin{array}{c}4.775 \text { (4.461 to } \\
5.111)\end{array}$ & $\begin{array}{c}4.380(4.089 \text { to } \\
4.692)\end{array}$ \\
\hline & No (reference category) & 22,908 & 1.000 & 1.000 & 1.000 & 1.000 \\
\hline \multirow{4}{*}{$\begin{array}{l}\text { Age group; (age } \\
\text { of main } \\
\text { shopper, years) }\end{array}$} & $18-34$ & 13,822 & $\begin{array}{c}1.146(1.040 \text { to } \\
1.262)\end{array}$ & $\begin{array}{c}1.102(0.996 \text { to } \\
1.219)\end{array}$ & $\begin{array}{c}0.980(0.916 \text { to } \\
1.049)\end{array}$ & $\begin{array}{c}0.991(0.922 \text { to } \\
1.065)\end{array}$ \\
\hline & $35-44$ & 18,995 & $\begin{array}{c}1.438(1.322 \text { to } \\
1.565)\end{array}$ & $\begin{array}{c}1.276(1.167 \text { to } \\
1.394)\end{array}$ & $\begin{array}{c}1.265 \text { (1.191 to } \\
1.342)\end{array}$ & $\begin{array}{c}1.191(1.118 \text { to } \\
1.269)\end{array}$ \\
\hline & $45-64$ & 32,426 & $\begin{array}{c}1.167(1.082 \text { to } \\
1.260)\end{array}$ & $\begin{array}{c}1.100(1.018 \text { to } \\
1.189)\end{array}$ & $\begin{array}{c}1.318(1.251 \text { to } \\
1.390)\end{array}$ & $\begin{array}{c}1.249(1.183 \text { to } \\
1.319)\end{array}$ \\
\hline & $\begin{array}{l}\text { 65+ (reference } \\
\text { category) }\end{array}$ & 14,168 & 1.000 & 1.000 & 1.000 & 1.000 \\
\hline \multirow{4}{*}{$\begin{array}{l}\text { Household } \\
\text { income group; } \\
\text { per adult per } \\
\text { household per } \\
\text { year, GB } \\
\text { pounds }\end{array}$} & $>£ 22.5 \mathrm{k}$ & 19,135 & $\begin{array}{c}1.556(1.441 \text { to } \\
1.681)\end{array}$ & $\begin{array}{c}1.157(1.059 \text { to } \\
1.265)\end{array}$ & $\begin{array}{c}0.961(0.911 \text { to } \\
1.014)\end{array}$ & $\begin{array}{c}0.858(0.806 \text { to } \\
0.914)\end{array}$ \\
\hline & $>£ 15-22.5 \mathrm{k}$ & 18,252 & $\begin{array}{c}1.294(1.194 \text { to } \\
1.403)\end{array}$ & $\begin{array}{c}1.047(0.960 \text { to } \\
1.142)\end{array}$ & $\begin{array}{c}1.063(1.008 \text { to } \\
1.121)\end{array}$ & $\begin{array}{c}0.958(0.903 \text { to } \\
1.016)\end{array}$ \\
\hline & $>£ 8.75-15 \mathrm{k}$ & 21,656 & $\begin{array}{c}1.078(0.995 \text { to } \\
1.168)\end{array}$ & $\begin{array}{c}0.989(0.911 \text { to } \\
1.074)\end{array}$ & $\begin{array}{c}0.919(0.872 \text { to } \\
0.968)\end{array}$ & $\begin{array}{c}0.892(0.845 \text { to } \\
0.942)\end{array}$ \\
\hline & $\begin{array}{c}>£ 0-8.75 \mathrm{k} \text { (reference } \\
\text { category) }\end{array}$ & 20,368 & 1.000 & 1.000 & 1.000 & 1.000 \\
\hline \multirow{4}{*}{$\begin{array}{l}\text { Social grade } \\
\text { group }\end{array}$} & AB (highest) & 17,179 & $\begin{array}{c}1.791(1.643 \text { to } \\
1.953)\end{array}$ & $\begin{array}{c}1.526(1.385 \text { to } \\
1.682)\end{array}$ & $\begin{array}{c}1.101(1.039 \text { to } \\
1.167)\end{array}$ & $\begin{array}{c}1.097(1.027 \text { to } \\
1.173)\end{array}$ \\
\hline & $\mathrm{C} 1$ & 14,494 & $\begin{array}{c}1.460(1.347 \text { to } \\
1.581)\end{array}$ & $\begin{array}{c}1.323(1.215 \text { to } \\
1.440)\end{array}$ & $\begin{array}{c}1.047(0.994 \text { to } \\
1.102)\end{array}$ & $\begin{array}{c}1.025(0.969 \text { to } \\
1.084)\end{array}$ \\
\hline & $\mathrm{C} 2$ & 31,325 & $\begin{array}{c}1.189 \text { (1.080 to } \\
1.309)\end{array}$ & $\begin{array}{c}1.095 \text { (0.992 to } \\
1.208)\end{array}$ & $\begin{array}{c}1.102(1.038 \text { to } \\
1.171)\end{array}$ & $\begin{array}{c}1.032(0.969 \text { to } \\
1.099)\end{array}$ \\
\hline & $\begin{array}{l}\text { DE (lowest) (reference } \\
\text { category) }\end{array}$ & 16,413 & 1.000 & 1.000 & 1.000 & 1.000 \\
\hline
\end{tabular}


Table 1. Cont.

\begin{tabular}{|c|c|c|c|c|c|c|}
\hline & & & \multicolumn{2}{|c|}{ Zero Alcohol Beer } & \multicolumn{2}{|c|}{ Low Alcohol Beer } \\
\hline & $\begin{array}{l}\text { Characteristics of } \\
\text { Consumers (Please } \\
\text { See Methods Section } \\
\text { for More Detail) }\end{array}$ & $n$ & $\begin{array}{l}\text { Univariate } \\
\text { Analysis }\end{array}$ & $\begin{array}{c}\text { Multivariate } \\
\text { Analysis }\end{array}$ & $\begin{array}{l}\text { Univariate } \\
\text { Analysis }\end{array}$ & $\begin{array}{c}\text { Multivariate } \\
\text { Analysis }\end{array}$ \\
\hline \multirow{4}{*}{$\begin{array}{l}\text { Area-based } \\
\text { residential } \\
\text { deprivation } \\
\text { group }\end{array}$} & 4 (least deprived) & 20,068 & $\begin{array}{c}1.412(1.307 \text { to } \\
1.525)\end{array}$ & $\begin{array}{c}1.233(1.135 \text { to } \\
1.340)\end{array}$ & $\begin{array}{c}0.976(0.925 \text { to } \\
1.029)\end{array}$ & $\begin{array}{c}0.983(0.927 \text { to } \\
1.042)\end{array}$ \\
\hline & 3 & 19,689 & $\begin{array}{c}1.197(1.105 \text { to } \\
1.296)\end{array}$ & $\begin{array}{c}1.113(1.025 \text { to } \\
1.208)\end{array}$ & $\begin{array}{c}0.988(0.937 \text { to } \\
1.043)\end{array}$ & $\begin{array}{c}0.984(0.930 \text { to } \\
1.041)\end{array}$ \\
\hline & 2 & 20,368 & $\begin{array}{c}1.082(0.998 \text { to } \\
1.173)\end{array}$ & $\begin{array}{c}1.030(0.948 \text { to } \\
1.119)\end{array}$ & $\begin{array}{c}0.962(0.912 \text { to } \\
1.015)\end{array}$ & $\begin{array}{c}0.988(0.935 \text { to } \\
1.045)\end{array}$ \\
\hline & $\begin{array}{l}1 \text { (most deprived) } \\
\text { (reference category) }\end{array}$ & 19,286 & 1.000 & 1.000 & 1.000 & 1.000 \\
\hline \multirow{11}{*}{$\begin{array}{c}\text { Region of Great } \\
\text { Britain }\end{array}$} & North East & 3873 & $\begin{array}{c}1.235(1.072 \text { to } \\
1.423)\end{array}$ & $\begin{array}{c}1.113(0.961 \text { to } \\
1.289)\end{array}$ & $\begin{array}{c}0.948(0.859 \text { to } \\
1.046)\end{array}$ & $\begin{array}{c}1.012(0.913 \text { to } \\
1.122)\end{array}$ \\
\hline & North West & 8715 & $\begin{array}{c}1.202(1.036 \text { to } \\
1.393)\end{array}$ & $\begin{array}{c}1.127(0.968 \text { to } \\
1.311)\end{array}$ & $\begin{array}{c}1.074(0.969 \text { to } \\
1.190)\end{array}$ & $\begin{array}{c}1.162(1.045 \text { to } \\
1.291)\end{array}$ \\
\hline & $\begin{array}{c}\text { Yorkshire and the } \\
\text { Humber }\end{array}$ & 8023 & $\begin{array}{c}0.882(0.737 \text { to } \\
1.056)\end{array}$ & $\begin{array}{c}.862(0.718 \text { to } \\
1.034)\end{array}$ & $\begin{array}{c}0.970(0.860 \text { to } \\
1.094)\end{array}$ & $\begin{array}{c}1.021(0.902 \text { to } \\
1.154)\end{array}$ \\
\hline & West Midlands & 7028 & $\begin{array}{c}1.275 \text { (1.095 to } \\
1.485)\end{array}$ & $\begin{array}{c}1.251(1.071 \text { to } \\
1.461)\end{array}$ & $\begin{array}{c}0.876(0.786 \text { to } \\
0.977)\end{array}$ & $\begin{array}{c}0.948(0.847 \text { to } \\
1.060)\end{array}$ \\
\hline & London & 5787 & $\begin{array}{c}0.987(0.846 \text { to } \\
1.151)\end{array}$ & $\begin{array}{c}0.965(0.825 \text { to } \\
1.128)\end{array}$ & $\begin{array}{c}1.032(0.929 \text { to } \\
1.145)\end{array}$ & $\begin{array}{c}1.121(1.007 \text { to } \\
1.248)\end{array}$ \\
\hline & East Midlands & 7150 & $\begin{array}{c}1.053(0.902 \text { to } \\
1.229)\end{array}$ & $\begin{array}{c}0.997(0.852 \text { to } \\
1.166)\end{array}$ & $\begin{array}{c}1.165 \text { (1.049 to } \\
1.294)\end{array}$ & $\begin{array}{c}1.199(1.077 \text { to } \\
1.335)\end{array}$ \\
\hline & South West & 7710 & $\begin{array}{c}0.943(0.800 \text { to } \\
1.112)\end{array}$ & $\begin{array}{c}0.914(0.774 \text { to } \\
1.081)\end{array}$ & $\begin{array}{c}0.714(0.635 \text { to } \\
0.801)\end{array}$ & $\begin{array}{c}0.822(0.729 \text { to } \\
0.926)\end{array}$ \\
\hline & Scotland & 6634 & $\begin{array}{c}0.967(0.827 \text { to } \\
1.132)\end{array}$ & $\begin{array}{c}0.931(0.795 \text { to } \\
1.091)\end{array}$ & $\begin{array}{c}1.115 \text { (1.004 to } \\
1.239)\end{array}$ & $\begin{array}{c}1.167(1.048 \text { to } \\
1.300)\end{array}$ \\
\hline & Wales & 4041 & $\begin{array}{c}1.114(0.958 \text { to } \\
1.295)\end{array}$ & $\begin{array}{c}1.068(0.918 \text { to } \\
1.243)\end{array}$ & $\begin{array}{c}1.249(1.128 \text { to } \\
1.383)\end{array}$ & $\begin{array}{c}1.267(1.142 \text { to } \\
1.405)\end{array}$ \\
\hline & Eastern & 8552 & $\begin{array}{c}0.916(0.787 \text { to } \\
1.066)\end{array}$ & $\begin{array}{c}0.892 \text { (0.766 to } \\
1.040)\end{array}$ & $\begin{array}{c}1.067 \text { (0.964 to } \\
1.182)\end{array}$ & $\begin{array}{c}1.085(0.979 \text { to } \\
1.204)\end{array}$ \\
\hline & $\begin{array}{l}\text { South East (reference } \\
\text { category) }\end{array}$ & 11,898 & 1.000 & 1.000 & 1.000 & 1.000 \\
\hline
\end{tabular}

Analyses adjusted for date of first household purchase of alcohol, and length of time (number of days) between first and last purchase of alcohol.

Households that were more likely to purchase zero alcohol beer were heavier purchasers of alcohol overall, and of beer with an ABV $>3.5 \%$, were of younger age groups (highest odds for 35-44 year olds) and were relatively affluent (i.e., from higher household incomes, 'higher' social grades, and less deprived residential areas). There was no consistent pattern by region of Great Britain.

Households that were more likely to purchase low alcohol beer were also heavier purchasers of alcohol overall, and of beer with an $\mathrm{ABV}>3.5 \%$, and were more likely to be middle-aged (45-64 years old) than from a younger or older age group. There was no consistent pattern by household income, social grade, level of residential deprivation, or region of Great Britain.

For purchase of zero alcohol beer, we also examined differences based on the social grade over time (Figure 2). The differences by social grade widened over time, and 
the absolute difference between social grade groups $\mathrm{AB}$ and $\mathrm{DE}$ increased by $0.0396 \%$ ( $95 \% \mathrm{CI}=0.0384$ to 0.0408 ) per every three months over the six years 2015 to 2020 .

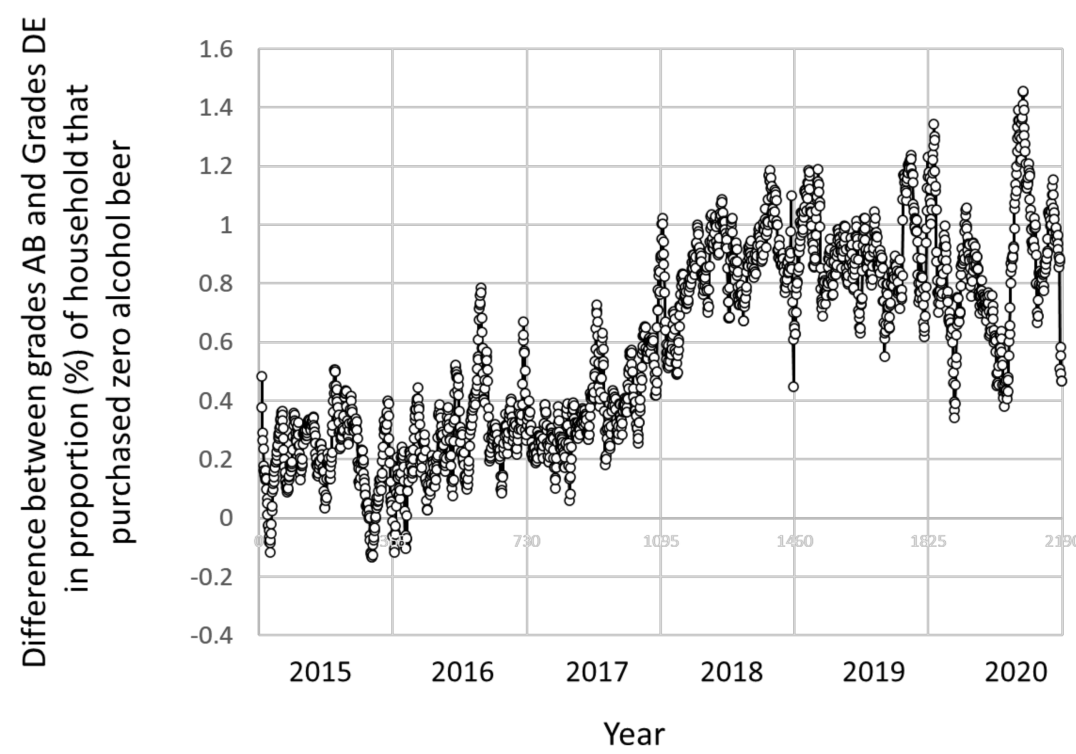

Figure 2. Absolute difference between social grades $\mathrm{AB}$ and $\mathrm{DE}$ in proportion (\%) of households that reported at least one purchase of zero alcohol for any day that a household made an alcohol purchase by study day, 2015 to 2020 . Data points: daily.

\subsection{Survey Data}

Based on the survey data, $0.34 \%(95 \% \mathrm{CI}=0.33$ to 0.36$)$ of respondents reported consuming at least one drink of zero alcohol beer during the previous week, $1.57 \%$ (95\% CI $=1.54$ to 1.60$)$ of low alcohol beer and $34.3 \%(95 \% \mathrm{CI}=34.0$ to 34.6$)$ of all other beer. The proportion for all other beer declined for the first two and a half years and then plateaued, Figure 3 (please note, the left vertical axis is for low and zero alcohol beer; and the right vertical axis is for all other beer). For low alcohol beer, there was a decrease during the first two years and then an increase; for zero alcohol beer, it remained low and fairly steady throughout, based on the survey data, $69.2 \%(95 \% \mathrm{CI}=67.6$ to 70.9$)$ of reported consumption of at least one zero alcohol beer during the previous week took place off-trade (i.e., purchased from supermarkets or off-licences); the proportions for low alcohol beer were $67.8 \%$ (95\% CI = 67.4 to 68.3$)$; and, for all other beer, $77.2 \%$ (95\% CI = 76.6 to 77.6$)$.

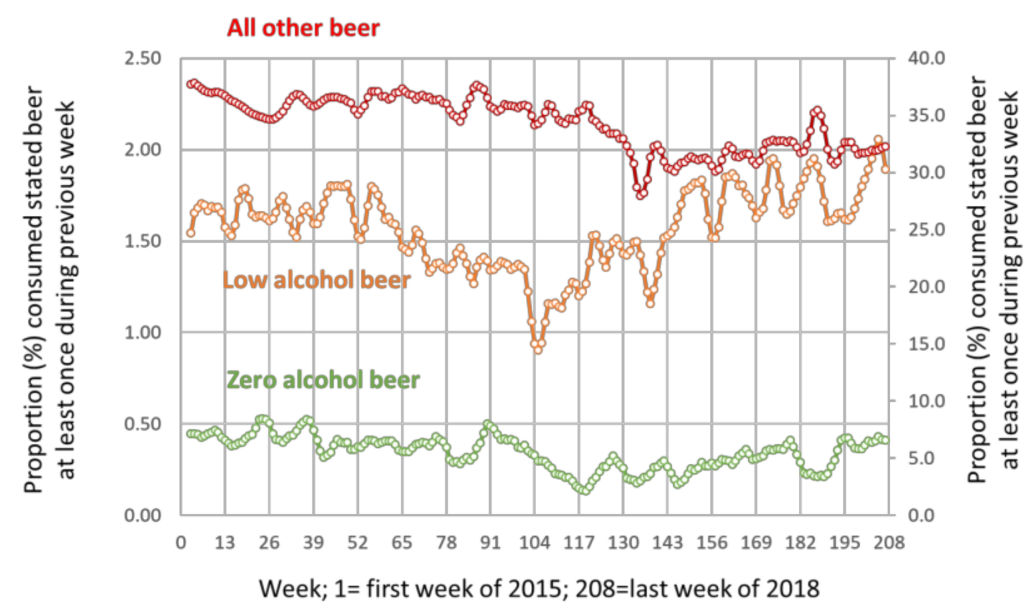

Figure 3. Proportion (\%) of survey respondents who reported consuming at least one drink of zero alcohol beer (green, left vertical axis), low alcohol beer (orange, left vertical axis) and all other beer (red, right vertical axis) by week, 2015 to 2018. 
Table 2 gives the odds ratios (95\% confidence intervals) for a respondent consuming at least one zero alcohol beer and at least one low alcohol beer during the previous week by respondent characteristics.

Table 2. Analysis at level of each respondent; odds ratios (OR) (95\% confidence intervals) for any consumption of zero alcohol beer $(\mathrm{ABV}=0.0 \%)$ or low alcohol beer $(\mathrm{ABV}>0.0 \%$ and $\leq 3.5 \%)$ during previous week by respondent sociodemographic characteristics. In bold: $95 \%$ confidence interval does not cross 1.0.

\begin{tabular}{|c|c|c|c|c|c|c|}
\hline & & & \multicolumn{2}{|c|}{ Zero Alcohol Beer } & \multicolumn{2}{|c|}{ Low Alcohol Beer } \\
\hline & $\begin{array}{l}\text { Characteristics of } \\
\text { Consumers (Please } \\
\text { See Methods Section } \\
\text { for More Detail) }\end{array}$ & $n$ & $\begin{array}{l}\text { Univariate } \\
\text { Analysis }\end{array}$ & $\begin{array}{l}\text { Multivariate } \\
\text { Analysis }\end{array}$ & $\begin{array}{l}\text { Univariate } \\
\text { Analysis }\end{array}$ & $\begin{array}{c}\text { Multivariate } \\
\text { Analysis }\end{array}$ \\
\hline \multirow{4}{*}{$\begin{array}{l}\text { Total grams of } \\
\text { alcohol } \\
\text { consumed } \\
\text { during } \\
\text { previous week }\end{array}$} & $>350$ & 7837 & $\begin{array}{c}2.938(2.192 \text { to } \\
3.937)\end{array}$ & $\begin{array}{c}1.654(1.210 \text { to } \\
2.260)\end{array}$ & $\begin{array}{c}6.220(5.454 \text { to } \\
7.093)\end{array}$ & $\begin{array}{c}3.471(3.012 \text { to } \\
4.000)\end{array}$ \\
\hline & $>200$ to $\leq 350$ & 9851 & $\begin{array}{l}2.296(1.710 \text { to } \\
3.082)\end{array}$ & $\begin{array}{c}1.400(1.028 \text { to } \\
1.908)\end{array}$ & $\begin{array}{c}3.885 \text { (3.377 to } \\
4.469)\end{array}$ & $\begin{array}{c}2.312(1.994 \text { to } \\
2.681)\end{array}$ \\
\hline & $>100$ to $\leq 200$ & 16,534 & $\begin{array}{l}1.670(1.271 \text { to } \\
2.195)\end{array}$ & $\begin{array}{l}1.061(0.795 \text { to } \\
1.416)\end{array}$ & $\begin{array}{l}2.686(2.353 \text { to } \\
3.067)\end{array}$ & $\begin{array}{c}1.657(1.440 \text { to } \\
1.906)\end{array}$ \\
\hline & $\begin{array}{c}\leq 100 \\
\text { (reference category) }\end{array}$ & 70,413 & 1.000 & 1.000 & 1.000 & 1.000 \\
\hline \multirow{2}{*}{$\begin{array}{l}\text { Consumed any } \\
\text { other beer with } \\
\text { ABV }>3.5 \%\end{array}$} & Yes & 35,864 & $\begin{array}{c}3.132(2.540 \text { to } \\
3.862)\end{array}$ & $\begin{array}{c}2.479(1.940 \text { to } \\
3.167)\end{array}$ & $\begin{array}{c}4.633(4.164 \text { to } \\
5.156)\end{array}$ & $\begin{array}{c}3.017(2.664 \text { to } \\
3.417)\end{array}$ \\
\hline & No (reference category) & 68,771 & 1.000 & 1.000 & 1.000 & 1.000 \\
\hline \multirow{2}{*}{ Gender } & Men & 53,409 & $\begin{array}{c}1.759(1.422 \text { to } \\
2.175)\end{array}$ & $\begin{array}{c}1.542(1.218 \text { to } \\
1.952)\end{array}$ & $\begin{array}{c}1.946(1.754 \text { to } \\
2.158)\end{array}$ & $\begin{array}{c}1.366(1.216 \text { to } \\
1.535)\end{array}$ \\
\hline & $\begin{array}{l}\text { Women (reference } \\
\text { category) }\end{array}$ & 51,226 & 1.000 & 1.000 & 1.000 & 1.000 \\
\hline \multirow{4}{*}{$\begin{array}{l}\text { Age group, } \\
\text { years }\end{array}$} & $18-34$ & 43,426 & $\begin{array}{l}3.845(2.381 \text { to } \\
6.209)\end{array}$ & $\begin{array}{c}3.935(2.406 \text { to } \\
6.437)\end{array}$ & $\begin{array}{c}3.340(2.655 \text { to } \\
4.201)\end{array}$ & $\begin{array}{c}3.713(2.927 \text { to } \\
4.709)\end{array}$ \\
\hline & $35-44$ & 18,718 & $\begin{array}{c}2.160(1.274 \text { to } \\
3.663)\end{array}$ & $\begin{array}{c}1.866(1.091 \text { to } \\
3.192)\end{array}$ & $\begin{array}{l}2.854(2.235 \text { to } \\
3.645)\end{array}$ & $\begin{array}{c}2.518(1.960 \text { to } \\
3.236)\end{array}$ \\
\hline & $45-64$ & 30,134 & $\begin{array}{c}1.223(0.717 \text { to } \\
2.086)\end{array}$ & $\begin{array}{l}1.196(0.700 \text { to } \\
2.044)\end{array}$ & $\begin{array}{c}1.487 \text { (1.160 to } \\
1.907)\end{array}$ & $\begin{array}{c}1.398(1.088 \text { to } \\
1.796)\end{array}$ \\
\hline & $\begin{array}{l}65+\text { (reference } \\
\text { category) }\end{array}$ & 12,357 & 1.000 & 1.000 & 1.000 & 1.000 \\
\hline \multirow{4}{*}{$\begin{array}{l}\text { Social grade } \\
\text { group }\end{array}$} & AB (highest) & 26,202 & $\begin{array}{c}1.894(1.432 \text { to } \\
2.504)\end{array}$ & $\begin{array}{c}1.352(1.014 \text { to } \\
1.803)\end{array}$ & $\begin{array}{c}1.392(1.214 \text { to } \\
1.597)\end{array}$ & $\begin{array}{c}0.961(0.833 \text { to } \\
1.109)\end{array}$ \\
\hline & $\mathrm{C} 1$ & 22,147 & $\begin{array}{c}1.745(1.300 \text { to } \\
2.344)\end{array}$ & $\begin{array}{c}1.140(0.839 \text { to } \\
1.551)\end{array}$ & $\begin{array}{c}1.530(1.331 \text { to } \\
1.759)\end{array}$ & $\begin{array}{c}1.017(0.877 \text { to } \\
1.179)\end{array}$ \\
\hline & $\mathrm{C} 2$ & 24,538 & $\begin{array}{c}1.094(0.792 \text { to } \\
1.512)\end{array}$ & $\begin{array}{l}0.986(0.710 \text { to } \\
1.369)\end{array}$ & $\begin{array}{c}1.281(1.111 \text { to } \\
1.476)\end{array}$ & $\begin{array}{c}1.054(0.910 \text { to } \\
1.221)\end{array}$ \\
\hline & $\begin{array}{l}\text { DE (lowest) (reference } \\
\text { category) }\end{array}$ & 31,748 & 1.000 & 1.000 & 1.000 & 1.000 \\
\hline \multirow{4}{*}{$\begin{array}{l}\text { Deprivation } \\
\text { group }\end{array}$} & 4 (least deprived) & 23,325 & $\begin{array}{c}0.713(0.534 \text { to } \\
0.953)\end{array}$ & $\begin{array}{c}0.764(0.563 \text { to } \\
1.038)\end{array}$ & $\begin{array}{c}0.827(0.723 \text { to } \\
0.946)\end{array}$ & $\begin{array}{c}0.903(0.782 \text { to } \\
1.044)\end{array}$ \\
\hline & 3 & 23,739 & $\begin{array}{l}0.661(0.492 \text { to } \\
0.889)\end{array}$ & $\begin{array}{l}0.722(0.531 \text { to } \\
0.981)\end{array}$ & $\begin{array}{l}0.742(0.646 \text { to } \\
0.852)\end{array}$ & $\begin{array}{c}0.832(0.719 \text { to } \\
0.962)\end{array}$ \\
\hline & 2 & 27,192 & $\begin{array}{c}0.926(0.716 \text { to } \\
1.197)\end{array}$ & $\begin{array}{c}0.950(0.728 \text { to } \\
1.238)\end{array}$ & $\begin{array}{c}0.812(0.714 \text { to } \\
0.924)\end{array}$ & $\begin{array}{c}0.862(0.753 \text { to } \\
0.986)\end{array}$ \\
\hline & $\begin{array}{l}1 \text { (most deprived) } \\
\text { (reference category) }\end{array}$ & 30,379 & 1.000 & 1.000 & 1.000 & 1.000 \\
\hline
\end{tabular}


Table 2. Cont.

\begin{tabular}{|c|c|c|c|c|c|c|}
\hline & & & \multicolumn{2}{|c|}{ Zero Alcohol Beer } & \multicolumn{2}{|c|}{ Low Alcohol Beer } \\
\hline & $\begin{array}{l}\text { Characteristics of } \\
\text { Consumers (Please } \\
\text { See Methods Section } \\
\text { for More Detail) }\end{array}$ & $n$ & $\begin{array}{l}\text { Univariate } \\
\text { Analysis }\end{array}$ & $\begin{array}{c}\text { Multivariate } \\
\text { Analysis }\end{array}$ & $\begin{array}{l}\text { Univariate } \\
\text { Analysis }\end{array}$ & $\begin{array}{c}\text { Multivariate } \\
\text { Analysis }\end{array}$ \\
\hline \multirow{11}{*}{$\begin{array}{l}\text { Region of Great } \\
\text { Britain }\end{array}$} & North East & 4474 & $\begin{array}{c}0.606(0.333 \text { to } \\
1.103)\end{array}$ & $\begin{array}{c}0.756(0.410 \text { to } \\
1.393)\end{array}$ & $\begin{array}{c}1.220(0.891 \text { to } \\
1.670)\end{array}$ & $\begin{array}{c}1.574(1.142 \text { to } \\
2.170)\end{array}$ \\
\hline & North West & 11,292 & $\begin{array}{c}0.783(0.431 \text { to } \\
1.421)\end{array}$ & $\begin{array}{c}0.950(0.519 \text { to } \\
1.740)\end{array}$ & $\begin{array}{c}1.133(0.818 \text { to } \\
1.570)\end{array}$ & $\begin{array}{c}1.465(1.051 \text { to } \\
2.042)\end{array}$ \\
\hline & $\begin{array}{c}\text { Yorkshire and the } \\
\text { Humber }\end{array}$ & 10,185 & $\begin{array}{c}0.698(0.339 \text { to } \\
1.439)\end{array}$ & $\begin{array}{c}0.789(0.381 \text { to } \\
1.635)\end{array}$ & $\begin{array}{c}0.990(0.675 \text { to } \\
1.453)\end{array}$ & $\begin{array}{c}1.086(0.737 \text { to } \\
1.601)\end{array}$ \\
\hline & West Midlands & 9544 & $\begin{array}{c}0.902(0.516 \text { to } \\
1.575)\end{array}$ & $\begin{array}{c}1.071(0.609 \text { to } \\
1.885)\end{array}$ & $\begin{array}{c}1.3380(0.982 \text { to } \\
1.822)\end{array}$ & $\begin{array}{c}1.641(1.198 \text { to } \\
2.247)\end{array}$ \\
\hline & London & 10,207 & $\begin{array}{c}0.669(0.357 \text { to } \\
1.253)\end{array}$ & $\begin{array}{c}0.820(0.435 \text { to } \\
1.546)\end{array}$ & $\begin{array}{c}0.932(0.663 \text { to } \\
1.312)\end{array}$ & $\begin{array}{c}1.170(0.827 \text { to } \\
1.654)\end{array}$ \\
\hline & East Midlands & 8961 & $\begin{array}{c}1.052(0.590 \text { to } \\
1.874)\end{array}$ & $\begin{array}{c}1.135(0.632 \text { to } \\
2.037)\end{array}$ & $\begin{array}{c}1.371(0.993 \text { to } \\
1.894)\end{array}$ & $\begin{array}{c}1.571 \text { (1.132 to } \\
2.181)\end{array}$ \\
\hline & South West & 9031 & $\begin{array}{l}2.208(1.310 \text { to } \\
3.721)\end{array}$ & $\begin{array}{c}1.899(1.122 \text { to } \\
3.214)\end{array}$ & $\begin{array}{c}2.370(1.754 \text { to } \\
3.203)\end{array}$ & $\begin{array}{c}2.142(1.579 \text { to } \\
2.907)\end{array}$ \\
\hline & Scotland & 13,383 & $\begin{array}{c}0.911(0.507 \text { to } \\
1.637)\end{array}$ & $\begin{array}{c}0.912(0.507 \text { to } \\
1.641)\end{array}$ & $\begin{array}{c}1.609(1.175 \text { to } \\
2.203)\end{array}$ & $\begin{array}{c}1.708(1.244 \text { to } \\
2.346)\end{array}$ \\
\hline & Wales & 4880 & $\begin{array}{c}0.666(0.361 \text { to } \\
1.230)\end{array}$ & $\begin{array}{c}0.677(0.366 \text { to } \\
1.251)\end{array}$ & $\begin{array}{c}1.337(0.972 \text { to } \\
1.839)\end{array}$ & $\begin{array}{c}1.400(1.015 \text { to } \\
1.931)\end{array}$ \\
\hline & Eastern & 10,077 & $\begin{array}{c}0.836(0.469 \text { to } \\
1.490)\end{array}$ & $\begin{array}{c}0.829(0.465 \text { to } \\
1.480)\end{array}$ & $\begin{array}{c}1.431(1.047 \text { to } \\
1.956)\end{array}$ & $\begin{array}{c}1.465(1.069 \text { to } \\
2.008)\end{array}$ \\
\hline & $\begin{array}{c}\text { South East (reference } \\
\text { category) }\end{array}$ & 12,601 & 1.000 & 1.000 & 1.000 & 1.000 \\
\hline
\end{tabular}

Analyses adjusted for date of completion of survey.

Respondents that were more likely to have consumed zero alcohol beer during the previous week were heavier drinkers of alcohol, consumers of beer with ABV $>3.5 \%$, men, of younger age groups and from 'higher' social grades, and, converse to the purchase data, from more deprived residential areas. There was no consistent pattern by region of Great Britain.

Respondents that were more likely to have consumed low alcohol beer during the previous week were heavier drinkers of alcohol, consumers of beer with ABV $>3.5 \%$, men, of younger age groups, from 'higher' social grades, and from more deprived residential areas. There was no consistent pattern by region of Great Britain.

\section{Discussion}

Although there were increasing purchases of zero alcohol beer and increasing consumption of low alcohol beer over time, we found relatively few occasions of purchases and consumption of zero and low alcohol beer throughout the time periods surveyed. For every purchase of zero alcohol beer, there were 32 purchases of beer with an $\mathrm{ABV}$ of $3.5 \%$ or more, and for every purchase of low alcohol beer, there were nearly 14 purchases of beer with an $\mathrm{ABV}$ of $3.5 \%$ or more. The differences in consumption during the previous week were even higher. For every consumption of at least one zero alcohol beer during the previous week, there were 101 consumptions of at least one beer with an ABV of 3.5\% or more, and for every consumption of at least one low alcohol beer, there were nearly 22 consumptions of at least one beer with an $\mathrm{ABV}$ of $3.5 \%$ or more.

Zero alcohol beer was more likely to be bought and drunk by those who generally bought and drank the most alcohol, those who bought and drank beer with an ABV $>3.5 \%$, 
men, those with younger ages, and those with higher incomes and higher social grades. There were differences between purchase and consumption by area of residential deprivation. Respondents from less deprived areas (i.e., those with lower incomes, more unemployment, poorer health and poorer housing, etc.) were more likely to purchase zero alcohol beer, but less likely to report recent consumption of zero alcohol beer (i.e., during the previous week). With univariate analyses, those who lived in the north of England were more likely to buy zero alcohol beer, with this difference no longer present in the multivariate analysis. Based on household level purchase data, results suggest the difference between higher and lower social grades increased over time between 2015 and 2020, favouring higher social grades.

Low alcohol beer was more likely to be bought and drunk by those who generally bought and drunk the most alcohol, those who bought and drunk higher strength beer $(\mathrm{ABV}>3.5 \%)$, men, those with younger ages, those with higher social grades, and those who lived in most deprived residential areas, and with no clear pattern by region of Great Britain.

Thus, although the data were not consistent across all socio-economic measures studied, it seemed that the purchase and consumption of zero and lower alcohol beers was greater amongst younger and more, rather than less, affluent households and respondents, and that the difference favouring the more affluent increased over time. We also found that buying and drinking zero and low alcohol beer was more common amongst those who bought and drunk the most alcohol overall and the most beer, as opposed to those who bought and drank lower amounts of alcohol overall and of beer. Given that we have previously demonstrated that the purchase of zero and lower alcohol beers amongst such heavier buyers of alcohol is associated with buying less grams of alcohol overall, and thus likely health benefit [11], the data might suggest that the promotion of zero and low alcohol beers could lead to increasing health inequalities.

Beyond the qualitative studies mentioned in the introduction [14,15], we are not aware of any published large-scale analyses that have investigated the socio-demographic characteristics of people who drink or purchase zero or low alcohol beer. Our data are consistent with broader behavioural risk factors, for which less healthy behaviours tend to cluster in lower social grades [24] as proposed by Bourdieu [25], with some evidence that innovation towards behaviours that may have less health risk occurs more rapidly amongst higher as opposed to lower social grade groups [26,27]. Zero alcohol beer might be part of purchase and consumption patterns that emerge as a consequence of people having better socioeconomic prospects and related lifestyles, or may be more evident in this group that, on average, buys and drinks more alcohol in Great Britain [28].

Our analyses have several important strengths and limitations. We obtained purchase data from a large number of households and survey data from a large number of respondents. Although relying on compliance at the household level, purchase data based on product bar codes, and verified via digital receipts, is, of itself, objective. The same cannot be said for the survey data which are based on subjective reports of drinking, with such subjective reports tending to underestimate consumption as measured by sales or other recorded data [29]. The timeline follow-back survey method has been criticized for the limited time period of drinking it covers, meaning it potentially misses heavy episodic drinking occasions among participants with a low frequency of such occasions. This limitation for classifying individuals is actually a strength when it comes to the characterization of population averages, however, where the shorter the time period, the smaller the biases due to memory, and the more accurate the population average [30].

Although quality control and compliance for the purchase data are regularly monitored by Kantar, with households only included in the final data set if they adhere to pre-assigned quality control criteria (meeting thresholds for data recording and purchasing volume or spend (based on household size) every four weeks), the data have limitations. Heavy drinkers, particularly male drinkers or those with no fixed address or living in communal establishments, are likely to be under-represented in household panel data [31,32] 
and that alcohol purchases are under-reported in general in these datasets [33]. For example, compared with the UK Living Costs and Food Survey, KWP households tend to have lower incomes, are more likely to be female headed (as main or primary shoppers), and their expenditure on certain commodity items, including alcohol, tends to be lower [34]. Lower recording of alcohol might reflect the method of recording purchases if not all items purchased are taken home and scanned. Whilst most primary shopping is done by women, secondary top-up shopping, which is more likely done by men, may be less well recorded [35]. Additionally, we are only able to assess changes in off-trade alcohol purchases as opposed to actual levels of alcohol consumption for these time periods. Adults in a household may not have an equal share of the alcohol purchased.

As with all survey-based research on alcohol, data cannot claim representativeness [36]. Representativeness needs to be based on probabilistic sampling design (i.e., all residents need to be assigned a probability $>0$ ) combined with high response rates unaffected by systematic non-response [37]. However, these conditions can no longer be reached in modern surveys involving alcohol, no matter which methodology is used $[36,38,39]$. Instead, post-stratification based on sex, age, social class, and geographical region was used to allow for generalizations to be made for the general population.

The data sets did not include underage drinkers. Finally, the data is just from one jurisdiction (Great Britain) and the findings may not, necessarily, be representative of other jurisdictions.

\section{Conclusions}

Although there is a growing trend [9], the present limited purchase and consumption of zero alcohol and low alcohol beer that our study identified implies that such products could only make a small contribution to efforts to reduce alcohol consumption. Thus, there remains an ongoing need to strengthen the implementation of the WHO SAFER alcohol policy measures to reduce the harm done by alcohol [4].

A key finding from our study is that younger and more socio-economically advantaged households and respondents were more likely to purchase and consume zero alcohol beer in particular. As such, policymakers should be careful in simply prioritising the increased availability of zero and low alcoholic products, as they may be disproportionally beneficial for already better-off populations and could potentially increase health inequalities. Rather, promoting the purchase and consumption of zero and low alcohol products, that may lead to less alcohol consumption [11], needs to go hand in hand with much needed structural policies that help to improve all people's socioeconomic prospects, aligned with approaches that address the social determinants of health $[40,41]$.

Author Contributions: P.A. conceptualized the paper and undertook the analyses. P.A., A.O., D.K., E.J.L. and E.K. contributed to the text, refined the various versions of the full paper and approved the final manuscript. The corresponding author attests that all listed authors meet authorship criteria and that no others meeting the criteria have been omitted. P.A. and A.O. are the guarantors of the data. P.A., A.O., D.K., E.J.L. and E.K. have read and agreed to the published version of the manuscript. All authors have read and agreed to the published version of the manuscript.

Funding: No funding was received in support of this study.

Institutional Review Board Statement: Not applicable.

Informed Consent Statement: Not applicable.

Data Availability Statement: Kantar Worldpanel data cannot be shared due to licensing restrictions.

Acknowledgments: We thank Kantar Worldpanel for providing the raw data and reviewing the method description as it describes the purchase data. E.K. is a National institute for Health Research (NIHR) Senior Investigator, and Director of the NIHR Applied Research Collaboration, North East and North Cumbria. A.O. is a National Institute for Health Research (NIHR) Advanced Fellow. The views expressed in this article are those of the authors and not necessarily those of NIHR, or the Department for Health and Social Care. 
Conflicts of Interest: E.J.L., A.O., D.K., and E.K. declare no competing interests and declare no financial relationships with any organizations that might have an interest in the submitted work in the previous three years. Within the previous five years, P.A. has received financial support from AB InBev Foundation outside the submitted work. All authors have completed the ICMJE uniform disclosure form at www.icmje.org/coi_disclosure.pdf (accessed on 30 August 2021) and declare no support from any organization for the submitted work; all authors declare no other relationships or activities that could appear to have influenced the submitted work.

\section{References}

1. Wood, A.; Kaptoge, S.; Butterworth, A.; Paul, D.; Burgess, S.; Sweeting, M.; Bell, S.; Astle, W.; Willeit, P.; Bolton, T.; et al. Risk thresholds for alcohol consumption: Combined analysis of individual-participant data for 599,912 current drinkers in 83 prospective studies. Lancet 2018, 391, 1513-1523. [CrossRef]

2. World Health Organization (WHO). Global Status Report on Alcohol and Health; WHO Press: Geneva, Switzerland, 2018. Available online: https:/ /apps.who.int/iris/bitstream/handle/10665/274603/9789241565639-eng.pdf?ua=1\&ua=1 (accessed on 30 August 2021).

3. World Health Organization. Global Action Plan for the Prevention and Control of NCDs 2013-2020; World Health Organization: Geneva, Switzerland, 2013.

4. World Health Organization (WHO). SAFER, Alcohol Control Initiative. 2020. Available online: https://www.who.int/substance_ abuse/safer/en/ (accessed on 30 August 2021).

5. World Health Organization. Global Strategy to Reduce the Harmful Use of Alcohol; World Health Organization: Geneva, Switzerland, 2010.

6. Rehm, J.; Lachenmeier, D.W.; Jané-Llopis, E.; Imtiaz, S.; Anderson, P. On the evidence base of reducing ethanol content in beverages to reduce the harmful use of alcohol. Lancet Gastroenterol. Hepatol. 2016, 1, 78-83. [CrossRef]

7. Capitello, R.; Todirica, I.C. Understanding the Behavior of Beer Consumers; Capitello, R., Maehle, N., Eds.; Woodhead Publishing: Sawston, UK, 2021; pp. 15-36, ISBN 9780128177341.

8. Salanță, L.C.; Coldea, T.E.; Ignat, M.V.; Pop, C.R.; Tofană, M.; Mudura, E.; Borșa, A.; Pasqualone, A.; Zhao, H. Non-Alcoholic and Craft Beer Production and Challenges. Processes 2020, 8, 1382. [CrossRef]

9. Corfe, S.; Hyde, R.; Shepherd, J. Alcohol-Free and Low-Strength Drinks Understanding Their Role in Reducing Alcohol-Related Harms. Available online: https://www.smf.co.uk/publications/no-low-alcohol-harms/ (accessed on 30 August 2021).

10. UK Government. Advancing our Health: Prevention in the 2020s-Consultation Document. 2019. Available online: https://www.gov.uk/government/consultations/advancing-our-health-prevention-in-the-2020s/advancing-our-healthprevention-in-the-2020s-consultation-document (accessed on 30 August 2021).

11. Anderson, P.; Llopis, E.J.; O'Donnell, A.; Manthey, J.; Rehm, J. Impact of low and no alcohol beers on purchases of alcohol: Interrupted time series analysis of British household shopping data, 2015-2018. BMJ Open 2020, 10, e036371. [CrossRef] [PubMed]

12. Hagemann, M.H.; Bogner, K.; Marchioni, E.; Braun, S. Chances for dry-hopped non-alcoholic beverages? Part 1: Concept and market prospects. Brew. Sci. 2016, 69, 50-55.

13. Hagemann, M.H.; Schmidt-Cotta, V.; Marchioni, E.; Braun, S. Chance for Dry-hopped Non-alcoholic Beverages? Part 2: Health Properties and Target Consumers. Brew. Sci. 2017, 70, 118-123. [CrossRef]

14. Chrysochou, P. Drink to get drunk or stay healthy? Exploring consumers' perceptions, motives and preferences for light beer. Food Qual. Prefer. 2014, 31, 156-163. [CrossRef]

15. Silva, A.P.; Jager, G.; van Bommel, R.; van Zyl, H.; Voss, H.-P.; Hogg, T.; Pintado, M.M.; de Graaf, C. Functional or emotional? How Dutch and Portuguese conceptualise beer, wine and non-alcoholic beer consumption. Food Qual. Prefer. 2016, 49 , 54-65. [CrossRef]

16. The Alcohol Change Report. 2018. Available online: https://alcoholchange.org.uk/get-involved/campaigns/the-alcoholchange-report (accessed on 30 August 2021).

17. Leicester, A.; Oldfield, Z.; Oldfield, Z. Using Scanner Technology to Collect Expenditure Data*. Fisc. Stud. 2009, 30, 309-337. [CrossRef]

18. Jakobsen, J.C.; Gluud, C.; Wetterslev, J.; Winkel, P. When and how should multiple imputation be used for handling missing data in randomised clinical trials-A practical guide with flowcharts. BMC Med. Res. Methodol. 2017, 17, 1-10. [CrossRef]

19. National Readership Survey. Social Class London: National Readership Survey. 2019. Available online: http://www.nrs.co.uk/ nrs-print/lifestyle-and-classification-data/social-grade/ (accessed on 10 July 2019).

20. GOV.UK. National Statistics: English Indices of Deprivation 2019. Available online: https://www.gov.uk/government/statistics/ english-indices-of-deprivation-2019 (accessed on 22 March 2021).

21. Gov.scot. Scottish Index of Multiple Deprivation (SIMD) 2020 Technical Notes. 2020. Available online: https:/ /www.gov.scot/ publications/simd-2020-technical-notes/ (accessed on 21 March 2021).

22. Gov.Wales. Welsh Index of Multiple Deprivation (full Index update with ranks). 2019. Available online: https://gov.wales/ welsh-index-multiple-deprivation-full-index-update-ranks-2019 (accessed on 30 August 2021).

23. IBM Corp. IBM SPSS Statistics for Windows, Version 26.0.; IBM Corp: Armonk, NY, USA, 2019. 
24. Anderson, P.; Llopis, E.J.; O'Donnell, A.; Kaner, E. Impact of COVID-19 Confinement on Alcohol Purchases in Great Britain: Controlled Interrupted Time-Series Analysis During the First Half of 2020 Compared With 2015-2018. Alcohol Alcohol. 2021, 56, 307-316. [CrossRef]

25. Tomlinson, M. Lifestyle and Social Class European Sociological Review. Eur. Sociol. Rev. 2003, 19, 97-111. [CrossRef]

26. Bourdieu, P. Distinction: A Social Critique of the Judgement of Taste; Harvard University Press: Cambridge, MA, USA, 1984.

27. Petrovic, D.; de Mestral, C.; Bochud, M.; Bartley, M.; Kivimaki, M.; Vineis, P.; Mackenbach, J.; Stringhini, S. The contribution of health behaviors to socioeconomic inequalities in health: A systematic review. Prev. Med. 2018, 113, 15-31. [CrossRef] [PubMed]

28. Pampel, F.C.; Krueger, P.M.; Denney, J.T. Socioeconomic Disparities in Health Behaviors. Annu. Rev. Sociol. 2010, 36, 349-370. [CrossRef]

29. Office for National Statistics. Adults drinking habits in Great Britain: 2017. 2018. Available online: https://www.ons.gov.uk/ peoplepopulationandcommunity/healthandsocialcare/drugusealcoholandsmoking/datasets/adultdrinkinghabits (accessed on 14 July 2021).

30. Kilian, C.; Manthey, J.; Probst, C.; Brunborg, G.S.; Bye, E.K.; Ekholm, O.; Kraus, L.; Moskalewicz, J.; Sieroslawski, J.; Rehm, J. Why Is Per Capita Consumption Underestimated in Alcohol Surveys? Results from 39 Surveys in 23 European Countries. Alcohol Alcohol. 2020, 55, 554-563. [CrossRef] [PubMed]

31. Stockwell, T.; Zhao, J.; Chikritzhs, T.; Greenfield, T.K. What did you drink yesterday? Public health relevance of a recent recall method used in the 2004 Australian National Drug Strategy Household Survey. Addiction 2008, 103, 919-928. [CrossRef]

32. Gill, J.; Black, H.; Rush, R.; O’May, F.; Chick, J. Heavy Drinkers and the Potential Impact of Minimum Unit Pricing-No Single or Simple Effect? Alcohol Alcohol. 2017, 52, 722-729. [CrossRef]

33. Gorman, E.; Leyland, A.; McCartney, G.; White, I.; Katikireddi, S.; Rutherford, L.; Graham, L.; Gray, L. Assessing the Representativeness of Population-Sampled Health Surveys Through Linkage to Administrative Data on Alcohol-Related Outcomes. Am. J. Epidemiol. 2014, 180, 941-948. [CrossRef] [PubMed]

34. Pechey, R.; Jebb, S.A.; Kelly, M.P.; Almiron-Roig, E.; Conde, S.; Nakamura, R.; Shemilt, I.; Suhrcke, M.; Marteau, T.M. Socioeconomic differences in purchases of more vs. less healthy foods and beverages: Analysis of over 25,000 British households in 2010. Soc. Sci. Med. 2013, 92, 22-26. [CrossRef]

35. Leicester, A. How might in-home scanner technology be used in budget surveys? In How Might In-Home Scanner Technology Be Used in Budget Surveys? IFS Working Paper W12/01/2012; The Institute for Fiscal Studies: London, UK, 2012.

36. Rehm, J.; Kilian, C.; Rovira, P.; Shield, K.D.; Manthey, J. The elusiveness of representativeness in general population surveys for alcohol. Drug Alcohol Rev. 2021, 40, 161-165. [CrossRef]

37. Kruskal, W.; Mosteller, F. Representative Sampling, III: The Current Statistical Literature. Int. Stat. Rev. 1979, 47, 245. [CrossRef]

38. Stedman, R.C.; Connelly, N.A.; Heberlein, T.A.; Decker, D.J.; Allred, S.B. The end of the (research) world as we know it? Understand-ing and coping with declining response rates to mail surveys. Soc. Nat. Resour. 2019, 32, 1139-1154. [CrossRef]

39. Habermann, H.; Kennedy, C.; Lahiri, P. A Conversation with Robert Groves. Stat. Sci. 2017, 32, 128-137. [CrossRef]

40. Marmot., M.; Wilkinson, R. (Eds.) Social Determinants of Health; Oxford University Press: Oxford, UK, 2005.

41. Marmot, M.; Bell, R. Social determinants and non-communicable diseases: Time for integrated action. BMJ $2019,364,1251$. [CrossRef] [PubMed] 